\title{
COMPARATIVE ANALYSIS OF ALTMAN Z-SCORE, SPRINGATE, ZMIJEWSKI AND OHLSON MODELS IN PREDICTING FINANCIAL DISTRESS
}

\author{
Putri Renalita Sutra Tanjung \\ Universitas Mercu Buana
}

Article DOI: $\underline{\text { https://doi.org/10.36713/epra4162 }}$

\begin{abstract}
This study aims to determine: (1) whether there is a difference between the Altman model, the Springate model, the Zmijewski model, and the Ohlson model in predicting financial distress. (2) the most accurate prediction model in predicting financial pain on a pharmaceutical company listed in IDX. The type of research is comparative descriptive. The sampling method used purposive sampling with 45 data from 9 pharmaceutical companies listed in IDX. Dependent and Independent variable is measured by ratio scale. Data analysis was performed by descriptive analysis, normality test, and paired sample t-test using SPSS program. Based on the result of these study indicate that : (1) There is a significant difference between the Altman model, the Springate model, the Zmijewski model, and Ohlson model in predicting financial distress, (2) The Altman model is the most accurate prediction model in predicting financial distress.
\end{abstract}

KEYWORDS: Altman, Springate, Zmijewski, Ohlson, Financial Distress

\section{INTRODUCTION}

Business continuity (Going Concern) of a company is one of the main objectives of a business entity since the establishment of the business entity, the survival of a business entity is very carefully related to how management manages the company both from financial and non-financial factors. The competitiveness of companies is also primarily determined by the performance of the company itself. Companies that show declining performance are feared to experience financial distress, and if not resolved immediately, the company will

Be threatened with bankruptcy as in pharmaceutical sector companies listed on the Stock Exchange where the sector experienced a slowdown in growth, and several companies suffered successive losses which, if not handled, will bring the company into financial distress. Financial distress is a situation where a company's operating cash flow does not adequately meet current obligations (such as credit trading or interest expenditure), and the company is forced to take corrective actions (Generous Sjahrial, 2014: 584). Problems that are allowed to drag on will eventually lead to bankruptcy. Of course, if that happens, many parties will be affected by this financial problem, both the company's private parties and the company's external parties. The financial distress condition of a company can be investigated before that happens. The earlier the signs of financial distress are known, the better it is for the company management to make improvements right from the start. Therefore, companies need to analyze to be able to predict the potential for financial distress that will occur so that companies can take appropriate steps. Various bankruptcy analysis models have been found, some of which are the Altman Z-Score Model, Zmijewski, Springate, and Ohlson. According to Anggi Meiliawati (2016), there are differences between Springate and Altman. In line with Januri's research (2017), there are differences in the bankruptcy potential of the three prediction models (Altman Z-Score, Zmijewski \& Springate).

Meanwhile, according to Liza Novietta (2017), there is no difference in scores between the Altman model, the Ohlson model, and the Zmijewski model in predicting financial distress. Bankruptcy analysis is essential to do with the consideration of the bankruptcy of a company that is going public will be detrimental to many parties. With indications of bankruptcy, the company's management can immediately take action to restructure debt because the liquidation effect of bankruptcy can be harmful to creditors and investors. By knowing the right bankruptcy prediction models, it is hoped that investors and other parties who are interested in 
analyzing financial difficulties can make better decisions.

\section{LITERATURE REVIEW Agency Theory}

According to Irham Fahmi (2014: 19-20) agency theory (agency theory) is a condition that occurs in a company where management as the executor is referred to further as an agent and capital owner as the principal building a cooperation contract called "nexus of commitment, "this cooperation contract contains agreements explaining that the company management must work

\section{Definition of Financial Distress}

According to Drescher (2014: 25), financial distress is the final stage of a liquidity crisis and potentially included in the bankruptcy stage. According to Brigham and Houston (2014: 111) states that financial distress occurs when the company experiences a state of inability to settle payments on time or when the cash flow from the company does not run smoothly.

According to Musthafa (2017: 202), financial difficulty is a condition in which a company is unable to meet its financial obligations, both short and long term. From some of the above understanding can be concluded that Financial distress is a condition where the company is facing financial difficulties. The state of financial trouble is illustrated by the inability of the company or the unavailability of funds to pay its obligations that are past due. Iskandar (2019), Financial distress is a stage of decline in the company's financial condition, and if this is allowed to continue, it will cause the company to go bankrupt. Types of Financial Distress

According to Irham Fahmi (2014: 95) Financial Distress in general studies, there are four categories of classification, namely Financial Distress category A or very high and dangerous. This category allows companies declared to be in a position of bankruptcy or bankruptcy. Financial Distress category B or high deemed hazardous. In this position, the company must think of various realistic solutions in saving

$$
Z=1.2 \mathrm{X} 1+1.4 \mathrm{X} 2+3.3 \mathrm{X} 3+0.6 \mathrm{X} 4+1.0 \mathrm{X} 5
$$

With the cut off value if the value of $Z<1.81$, then the company is predicted to go bankrupt if the value of $1.81<\mathrm{Z}<2.99$, the company is prone to bankruptcy and if $Z>2.99$ the condition of the company is healthy or not bankrupt. different assets owned, such as sources of assets that want to be sold and not sold/maintained.

Financial Distress category $\mathrm{C}$ or medium, where the company is considered still able to save themselves with additional funds from internal and external sources. Financial Distress category D or low. In this category, the company is deemed to be only experience temporary economic fluctuations caused by a variety of external and internal conditions, including others, and a less precise decision is made.

\section{Causes of Financial Distress}

According to Ahmad Rodoni (2014: 189), From the financial aspect, three circumstances can cause financial distress, namely the factor of capital insufficiency or lack of capital, the amount of debt and interest burden, and suffering losses. While the causes of financial pain from macroeconomic factors are uncertainty of a country's economic conditions such as inflation and foreign exchange rates.

\section{Overcoming Financial Distress}

According to Hanafi and Halim (2014: 262), alternatives to improving financial difficulties are as follows:

1. The internal solution is done if the problem is not so severe, the company's problem is only temporary, by asking for an extension of the debt maturity and reducing the amount of the bill

2. Formal solution is done when the problem is severe; the creditor wants to have security guarantees by reorganizing the capital structure to become a decent capital structure and liquidating if it cannot be continued, namely by selling the company's assets.

\section{Financial Distress Prediction Model}

\section{Altman Z-Score Model}

Altman was the first person to implement Multiple Discriminant Analysis (MDA). The result was that Z-score was able to predict the potential bankruptcy of a company in a continuous and general manner. After researching selected variables and samples, Altman produced the first bankruptcy model. Bankruptcy equation aimed at predicting a public manufacturing company. The equation of the first Altman model viz

\section{Springate Model}

This model was developed in 1978 by Gorgon L.V. Springate. Following the procedure developed by Altman, Springate uses step-wise multiple discriminate analysis to select four of the 19 popular financial ratios to distinguish between companies that are in the bankrupt or safe zone. The Springate Model formulates as follows:

$$
\mathrm{S}=1.03 \mathrm{X} 1+3.07 \mathrm{X} 3+0.66 \mathrm{X} 6+0.4 \mathrm{X} 5
$$


With a cut off value $\mathrm{S}<0.862$, it is said to be bankrupt, if $0.862<\mathrm{S}<1.062$ it is said to be bankrupt and if $\mathrm{S}>1.062$ is not bankrupt.

\section{Zmijewski Model (X-Score)}

Zmijewski (1983) conducted a study by reviewing the study of bankruptcy in the field of the results of previous research for twenty years. Several financial ratios were selected from previous research financial ratios. They sampled as many as 75 companies that went bankrupt, as well as 3573 healthy companies during 1972 to 1978 , F-test indicators to group ratios, Rate of Return, liquidity, leverage, turnover, fixed payment coverage, trends, firm size, and stock return volatility, show a significant difference between healthy and unhealthy companies. The following is the model formulated by Zmijewski:

$$
\mathrm{X} \text {-score }=-4.3-4.5 \mathrm{X} 7+5.7 \mathrm{X} 8-0.004 \mathrm{X} 9
$$

cut off point of 0 (zero). If the X-Score is below the cutoff point, the company is in a healthy condition. However, the X-Score is above the cutoff point, and the company is in financial distress

\section{Ohlson Model (O-Score)}

Y-score bankruptcy prediction method was started by James A. Olson (1980) in his journal entitled Financial Ratio and the Probabilistic Prediction of Bankruptcy. Ohlson uses logistic analysis to avoid problems about assumptions in the
Multiple Discriminant Analysis (MDA) model conducted by Altman, ie the data being tested requires data normality requirements. Unlike most prediction models conducted by previous researchers, this model includes the firm size variable as a research variable. Ohlson assumes that large companies have smaller financial distress possibilities because large companies usually develop and operate well and are relatively stable. The Ohlson (1980) model equation is as follows:

$$
\mathrm{O}=-1.32-0.407 \mathrm{X} 1+6.03 \mathrm{X} 2-1.43 \mathrm{X} 3+0.0757 \mathrm{X} 4-2.37 \mathrm{X} 5-1.83 \mathrm{X} 6+0.285 \mathrm{X} 7-1.72 \mathrm{X} 8-0.521 \mathrm{X} 9
$$

Ohlson (1980) states that this model has an optimal cutoff point of 0.38 . The purpose of this cutoff is that a company that has an $\mathrm{O}$ score of more than 0.38 means that the company is predicted to experience financial distress. Conversely, if the company's $\mathrm{O}$ score is less than 0.38 , then the company is predicted not to be financial distress

\section{Past Research}

Jones (2016) A Cash Flow-Based Model of Corporate Bankruptcy in Australia develops a cash flow model by using net operating variables cash flow to total assets, quality of earnings (operating cash flow to EBIT), cash flow cover, and cash position to total assets. This study also shows that the Altman Z Score fails to predict financial distress in sample companies, and the Case-based model is much better than Altman. Case-based models can predict that financial pain will occur in the sample companies at least six months before the condition occurs in the company.

The results of Fawzi et al (2015) study of 104 companies in Malaysia in 2009-2012 using logit regression proved that the 5 (five) cash flow ratios were significant financial distress predictors, and the prediction accuracy reached $82.1 \%$.

Alostaz's (2015) research on companies listed on the Palestinian stock exchange proves that the cash-flow industry sector that is significant in predicting bankruptcy includes cash flow coverage of interest ratio, operating cash-flow margin ratio, and free cash flow on current liabilities ratio. By using logistic regression, the prediction accuracy reaches $80 \%$.
Hidayat (2015) Analysis in Predicting Bankruptcy Using Multiple Discriminant Analysis and Logit in the Pharmaceutical Industry Listed on the Indonesia Stock Exchange Period 2009-2014 Of the ten testing methods there are six of them experiencing differences in predicting bankruptcy namely Altman with Springate, Altman with Zmijewski, Altman with Olhson, Springate with Zmijewski, and Springate with Olhson.

The research of Dewi Anggraini and Hadri Mulya (2016) used Binary logistic regression analysis method, which found the influence of financial distress prediction on several financial ratios such as: Working Capital to Total Assets; Current Ratio; Book value of equity to Total Liabilities; Total Debt to Total Assets; EBIT to Current Liabilities; and Institutional Ownership.

Fardinal and Gandhy (2019) research states that liquidity ratios and solvency ratios have a substantial negative relationship to financial distress, while profitability ratios have a robust positive correlation.

Veronita (2014) Comparative Analysis of the Altman, Springate, Ohlson, Fulmer, CA-Score and Zmijewski Models in Predicting Financial Distress (empirical studies on Food and Beverages Companies Listed on the Indonesia Stock Exchange in the 2010-2012 Period) There are differences between the Ohlson, Altman Model, Springate, and Zmijewski. Ohlson's model has the highest level of conformity compared to the Altman, Springate, and Zmijewski models. The Springate model has the lowest compliance. 
Putera et al. Comparison of Financial Distress Predictions Using the Altman, Springate, and Ohlson Models The results of hypothesis testing with the Kruskall-Wallis test concluded that there were no differences in financial distress predictions with the Altman, Springate and Ohlson models.

Permana et al.(2017) Financial Distress Prediction in Manufacturing Companies on the Indonesia Stock Exchange There is differences in health status in testing the Grover, Springate, and
Zmijewski models. The Springate model is the best prediction model compared to the Grover and Springate models because it has more components than the other two models.

\section{Framework}

Based on the periodization chosen in this study and the previous description, the theoretical framework of this research is described as follows:

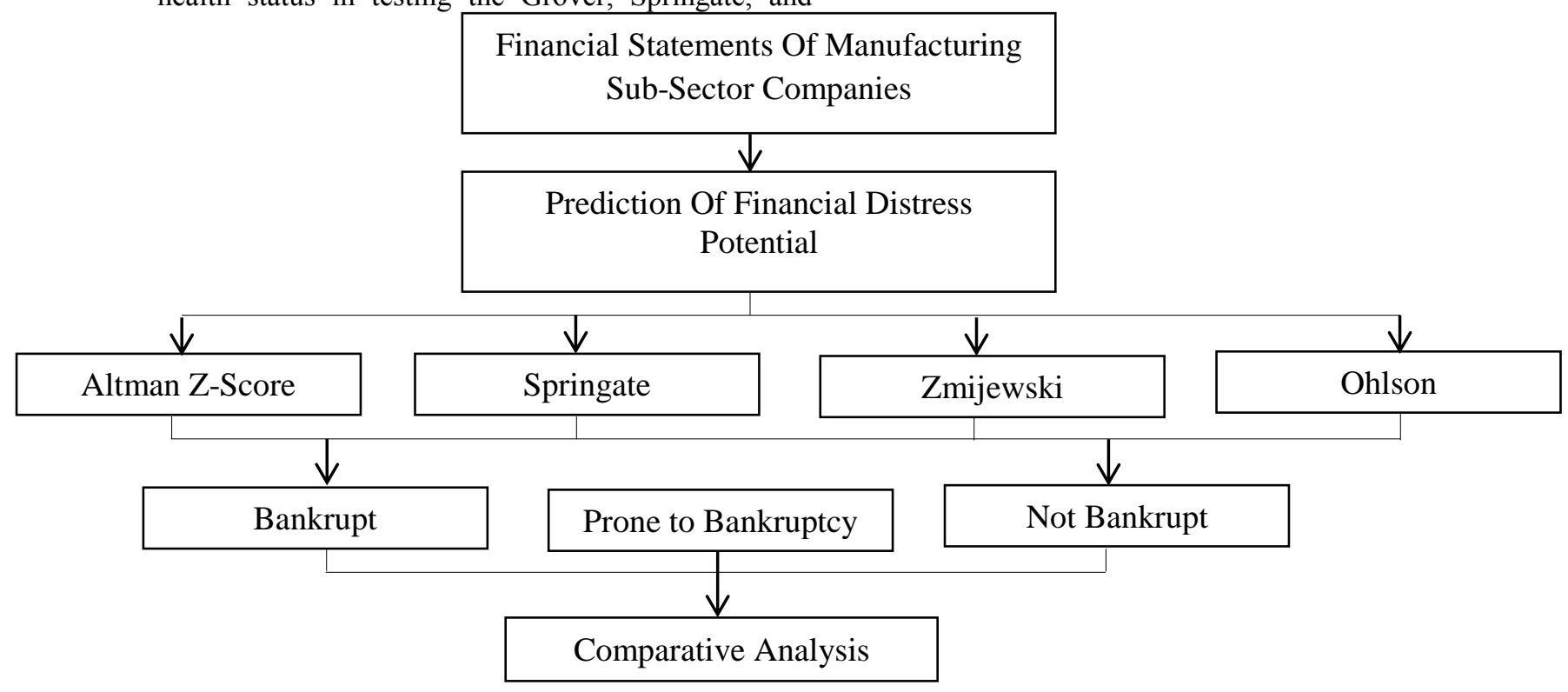

Figure 1. Framework

\section{Research Hypothesis}

H1 : There is a difference in the results of the analysis of financial distress potential between the Altman Z-Score and Springate models

H2: There are differences in the results of the study of potential financial distress between the Altman Z-Score model and Zmijewski

H3: There is a difference in the results of the analysis of the potential for financial distress between the Altman Z-Score model and Olson

H4: There is a difference in the results of the analysis of the potential for financial distress between the Springate and Zmijewski models

H5: There is a difference in the results of the analysis of the potential for financial distress between the Springate and Ohlson models

H6: There are differences in the results of the analysis of the potential for financial distress between the Zmijewski and Ohlson models

\section{RESEARCH METHODS}

The research design used by the author in this study is comparative descriptive. Comparing the results of the bankruptcy prediction analysis of the Altman Z-Score model, the Springate model, the Zmijewski model, and the Ohlson model. The dependent variable in this study is Financial Distress. Independent variables in this study are the Altman Z-Score, the Springate model, the Zmijewski model, and the Ohlson model. The sample in this study is a pharmaceutical sector company listed on the Indonesia Stock Exchange. The sampling method used in this study is the Purposive Sampling method; there are 45 data from 9 samples. The purpose of the analysis uses descriptive statistics, variable measurements, normality tests, and hypothesis tests. 


\section{RESEARCH RESULTS AND DISCUSSION Descriptive Statistics Analysis 1. Descriptive Altman Model}

Table 1. Descriptive Altman Model Descriptive Statistics

\begin{tabular}{|l|c|c|c|c|c|}
\hline & N & Minimum & Maximum & Mean & $\begin{array}{c}\text { Std. } \\
\text { Deviation }\end{array}$ \\
\hline WCTA & 45 & .03 & .69 & .4212 & .16935 \\
RETA & 45 & .09 & .77 & .4501 & .20956 \\
EBITTA & 45 & -.03 & .48 & .1713 & .12881 \\
MVETL & 45 & .00 & 46.90 & 15.5636 & 14.70690 \\
SALESTA & 45 & .78 & 1.76 & 1.1877 & .23351 \\
SCORE & 45 & 1.73 & 30.37 & 12.2267 & 9.23682 \\
Valid N (listwise) & 45 & & & & \\
\hline
\end{tabular}

The maximum value of the WCTA ratio is 0.69 , which means that in 1 rupiah, total assets have 0.69 working capital, indicating ineffective fund management. While the minimum value of 0.03 means that in 1 rupiah of total assets, there is 0.03 working capital, the value of the ratio can be said that the company has a problem with its liquidity. RETA ratio of a minimum value of 0.091 . The maximum amount is 0.77 . EBITTA ratio of minimum value -0.03 because the company suffered losses, the maximum value of 0.48 , which means the company has an excellent performance. MVETL Ratio Minimum value of 0.003 because it has a low market value compared to the total debt. The maximum value is 46.90 because it has a higher market value of 46.90 times compared to its total debt. SALESTA ratio of a minimum value of 0.78 means that every 1 rupiah of total assets results in sales of 0.78 . The maximum value of 1.76 shows that this year the company is very effective in using its assets. The average score of the Altman model score of 12.22 shows that the condition of pharmaceutical companies in the situation does not experience financial distress. Still, a minimum value of 1.73 enters bankruptcy-prone states. The maximum value of 30.37 financial terms in the company is in excellent condition.

\section{Descriptive Springate Model}

Table 2. Descriptive Springate Model Descriptive Statistics

\begin{tabular}{|l|c|c|c|c|c|}
\hline & N & Minimum & Maximum & Mean & Std. Deviation \\
\hline WCTA & 45 & .03 & .69 & .4212 & .16935 \\
EBITTA & 45 & -.03 & .48 & .1713 & .12881 \\
EBTCL & 45 & -.09 & 3.27 & 1.0414 & .98082 \\
SALESTA & 45 & .78 & 1.76 & 1.1877 & .23351 \\
SCORE & 45 & .40 & 4.47 & 2.1221 & 1.09782 \\
Valid N (listwise) & 45 & & & & \\
\hline
\end{tabular}

The maximum value of the WCTA ratio is 0.69 , which means that in 1 rupiah, total assets have 0.69 working capital, indicating ineffective fund management. While the minimum value of 0.03 , which means that in 1 rupiah of total assets, there is 0.03 working capital, the value of the ratio can be said that the company has a problem in its liquidity. EBITTA ratio minimum value of -0.03 because the company suffered losses, the maximum amount of 0.48 , which means the company has an excellent performance. EBITCL ratio of a minimum value of -0.09 because the company has a negative profit. The maximum amount is 3.27 , which means that every 1 rupiah of current debt is guaranteed or borne by Rp.
3.27 of profit before corporate tax. SALESTA ratio of a minimum value of 0.78 means that every 1 rupiah of total assets results in sales of 0.78 . The maximum value of 1.76 shows that this year the company is beneficial in using its assets. The average value of the Springate Model of 2.12 is higher than the cut-off value of 1,062, which means that most pharmaceutical companies are in a healthy financial condition. The minimum amount of 0.40 so that the company is categorized in financial distress. The maximum amount of 4.47 companies has the best performance with a ratio value that is all good. 


\section{Descriptive Model of Zmijewski}

Table 3. Descriptive Model of Zmijewski

Descriptive Statistics

\begin{tabular}{|l|c|c|c|c|c|}
\hline & $\mathbf{N}$ & Minimum & Maximum & Mean & $\begin{array}{c}\text { Std. } \\
\text { Deviation }\end{array}$ \\
\hline EATTA & 45 & -.042 & .363 & .12739 & .104602 \\
TLTA & 45 & .069 & .656 & .30751 & .149447 \\
CACL & 45 & 1.042 & 10.254 & 3.54186 & 2.121872 \\
SCORE & 45 & -4.914 & -.429 & -3.13464 & 1.214422 \\
Valid N (listwise) & 45 & & & & \\
\hline
\end{tabular}

EATTA Ratio Minimum value of -0.042 shows that the company is not able to generate profits in using assets. A maximum amount of 0.363 means that every 1 rupiah of total assets makes a net profit of Rp 36.3. TLTA ratio of minimum value of 0.069 shows that assets of $6.9 \%$ are financed by debt; this indicates that the condition of the company's solvency is good. The maximum value of 0.656 , which means that assets of $65.6 \%$ are financed by debt, the ratio of debt to assets that exceed $50 \%$ indicates the condition of the company's solvency that is not good. CACL Ratio
Minimum value of 1.04 , which means that every 1 rupiah is guaranteed by current assets worth $\mathrm{Rp} 1.04$. The maximum value of 10.25 shows that existing assets of Rp guarantee every 1 rupiah of existing debt. 10.25. The average score of the Zmijewski model score is -3.13 smaller than the cut-off value of this model of 0 , meaning that most pharmaceutical companies are in a healthy financial condition. A minimum value of -4.91 means that the company is in good financial condition and a maximum amount of -0.42 .

\section{Descriptive Ohlson Model}

Table 4. Descriptive Ohlson Model Descriptive Statistics

\begin{tabular}{|l|c|c|c|c|c|}
\hline & $\mathbf{N}$ & Minimum & Maximum & Mean & $\begin{array}{c}\text { Std. } \\
\text { Deviation }\end{array}$ \\
\hline LogTAGNP & 45 & .694 & .819 & .76138 & .035263 \\
TLTA & 45 & .069 & .656 & .30753 & .149448 \\
WCTA & 45 & .025 & .691 & .42118 & .169354 \\
CLCA & 45 & 1.042 & 10.254 & 3.54189 & 2.121798 \\
NITA & 45 & -.042 & .363 & .12736 & .104639 \\
CFOTL & 45 & -.395 & 2.789 & .64442 & .715267 \\
NITNIT & 45 & -8.161 & 2.216 & -.10782 & 1.290319 \\
SCORE & 45 & -1.695 & 4.151 & -.21767 & 1.080101 \\
Valid N (listwise) & 45 & & & & \\
\hline
\end{tabular}

The Log Ratio (total assets / GNP price-level index) is known to be a minimum value of 0.69 and a maximum value of 0.81 . A TLTA ratio of a minimum value of 0.069 indicates that assets of $6.9 \%$ are financed by debt, indicating that the condition of the company's solvency is good. The maximum value of 0.656 , which means that assets of $65.6 \%$ are financed by debt, the ratio of debt to assets that exceed $50 \%$ indicates the condition of the company's solvency that is not good. The maximum value of the WCTA ratio is 0.69 , which means that in 1 rupiah, total assets have 0.69 working capital, indicating ineffective fund management. While the minimum value of 0.03 means that in 1 rupiah of total assets, there is 0.03 working capital, the value of the ratio can be said that the company has a problem with its liquidity. The CLCA ratio is a minimum value of 1.04 and a maximum value of 10,254 . The NITA ratio is a minimum value of $-0,042$ because the company has a loss and a maximum value of 0.363 , which means assets valued at 1 rupiah produce a net profit of 0.363 . CFOTL ratio of minimum value -0.395 and maximum value of 2789. The ratio (Nit-Nit-1) / (Nit + Nit-1) minimum value is -8.161 and maximum value is 2.216. The average Ohlson score is -0.217 smaller than the cut-off value of 0.38 , which means that most financial conditions in pharmaceutical companies are in good health. The minimum value is -1.695 , and the maximum value is 4151 .

\section{Financial Distress Analysis Results 1. Altman Z-Score Model}

Based on the results of the Altman model calculation, there are no companies that are predicted to go bankrupt, but there are some companies that are declared bankrupt, such as PT. Indofarma (Persero) Tbk. in 2013 until 2015 has a cut-off value $Z$ score prone to bankruptcy, it is because in 2013 PT. Indofarma (Persero) Tbk. Has a negative value of X3 (Earning Before Interest Tax to Total Assets), the 
company suffers losses, causing its $Z$ Score to be at the point of bankruptcy. Companies that are also categorized as bankrupt are PT. Pyridam Farma Tbk. in 2013 - 2015 this is because the value of debt is higher than the market value which can be seen in the amount of the Market value equity/book value of debt ratio where this ratio measures the company's ability to provide guarantees to each debt through its capital. Neither the company PT. Tempo Scan Pacific Tbk in 2015 and 2017, although in general, the value of the ratio is good because the debt value is higher than the market value, the company has a $\mathrm{Z}$ Score in the category of bankruptcy in that year.

\section{Springate Model}

Based on the calculation of the Springate model, some companies are predicted to experience bankruptcy for five consecutive years, namely PT. Indofarma (Persero) Tbk. in the calculation result table, it can be seen that the EBIT / TA ratio and the EBT / CL ratio in 2013 were negative, this indicates a problem with the company's profitability capability. However, in 2014 and 2015, all rates had positive values but could not significantly affect the $\mathrm{S}$ score, so the results remain in the bankrupt category. In 2016 and 2017, the company returned the results of the EBIT / TA ratio and the negative EBT / CL ratio, followed by a decrease in the WC / TA and SALES / $\mathrm{TA}$ ratio results.

\section{Zmijewski model}

Based on the results of calculations on the Zmijewski model, no company is predicted to experience bankruptcy in the 2013-2017 period.

\section{Ohlson's Model}

Based on the results of the Ohlson model calculation, some companies are predicted to experience bankruptcy, namely PT. Indofarma (Persero) Tbk in 2013 - 2015 and 2017, PT. Kimia Farma (Persero) Tbk. in 2015 - 2017 and PT. Pyridam Farma Tbk in 2013 - 2015. On the financial condition of PT. Indofarma (Persero) Tbk in 2013-2015 where the state of the company was declared experiencing financial difficulties influenced by an increase in total debt but not offset by an increase in profits, but the losses suffered by the company means the company is unable to process the capital obtained from liability to generate profits. At PT. Kimia Farma (Persero) Tbk. Predicted an increase in net profit did not accompany bankruptcy in 2015 - 2017 due to the rise in the amount of debt in 2015 by $6 \%$ but this increase in debt because the company experienced a decrease in net income by $2 \%$ than in 2016 total debt still experienced a significant increase namely by $40 \%$ and similarly in 2017 , this condition made $\mathrm{O}$ scores increase and included companies in the financial distress category.

\section{Recap of the Calculation Results of the Altman Z-Score, Springate, Zmijewski, and Ohlson Models}

Table. 5 .Recap of the Calculation Results of the Altman Z-Score, Springate, Zmijewski, and Ohlson Models

\begin{tabular}{|c|c|c|}
\hline \multirow{2}{*}{ Model } & \multicolumn{2}{|c}{ Predictio } \\
\cline { 2 - 3 } & $\begin{array}{c}\text { Financial } \\
\text { Distress }\end{array}$ & Grey \\
\hline Altman Z-Score & 0 & 8 \\
\hline Springate & 7 & 2 \\
\hline Zmijewski & 0 & 0 \\
\hline Ohlson & 10 & \\
\hline
\end{tabular}

Altman Z-Score model, no one is predicted to experience the condition of Financial Distress. This is by the real terms in the company where until now, the company is still listed on the Indonesia Stock Exchange. However, this model predicts 8 (eight) companies are prone to Financial Distress, the prediction is by the real condition of the company where the anticipated company suffered losses and also an increase in debt that is not matched by the company's ability to guarantee its debt. In the Springate Model, it is predicted that 7 (seven) companies experience financial distress. This model has relatively strict limits in determining the condition of the company. The company is still able to cover these losses with sufficient working capital.

In the Zmijewski Model, no company is predicted to experience financial distress; this is by sample of companies is still listed on the Intone Stock Exchange. However, this model does not predict or warn companies that are prone to experiencing financial distress, which in fact, some samples of companies experience losses and increase in debt resulting in companies prone to experiencing financial difficulties. In the Ohlson Model, it is predicted that there are 10 (ten) companies that experience financial distress, this is not by the real condition of the company where until now the company is still listed on the Indonesia Stock Exchange, which means the company is still able to manage its finances well. From the four results of the model, it can be concluded that the Altman Z-Score model is the most accurate in predicting the company's financial condition, whether in financial distress, prone to financial distress, or non-financial distress. Because this model is by the real terms of the 
EPRA International Journal of Multidisciplinary Research (IJMR) - Peer Reviewed Journal Volume: 6 | Issue: 3 | March 2020 || Journal DOI: 10.36713/epra2013 || SJIF Impact Factor: 5.614||ISI Value: 1.188

company that was sampled in this study. This is in line with previous studies of Safinatun (2019) that the
Altman Z-Score has a higher level of accuracy than other models

\section{Normality Test Results}

\section{Altman Model Normality Test Results}

Table 6. Altman Model Normality Test Results One-Sample Kolmogorov-Smirnov Test

\begin{tabular}{|ll|c|}
\hline & & $\begin{array}{c}\text { Unstandardize } \\
\mathrm{d} \text { Residual }\end{array}$ \\
\hline $\mathrm{N}$ & Mean & 45 \\
Normal Parameters $\mathrm{a}, \mathrm{b}$ & Std. Deviation & .0000000 \\
& Absolute & .060 \\
& & .048 \\
Most Extreme Differences & Positive & -.060 \\
& Negative & .403 \\
Kolmogorov-Smirnov Z & & .997 \\
Asymp. Sig. (2-tailed) & & \\
\hline
\end{tabular}

a. Test distribution is Normal.

b. Calculated from data.

Based on the table in the table above the Kolmogorov-Smirnov $\mathrm{Z}$ value is 0.403 and a probability value of 0.997 shows that the probability

value is greater than the significant value of 0.05 , so it can be concluded that the data are normally distributed.

\section{Springate Model Normality Test Results}

Table 7. Springate Model Normality Test Results One-Sample Kolmogorov-Smirnov Test

\begin{tabular}{|ll|c|}
\hline & & $\begin{array}{c}\text { Unstandardiz } \\
\text { ed Residual }\end{array}$ \\
\hline $\mathrm{N}$ & Mean & 45 \\
Normal Parameters ${ }^{\mathrm{a}, \mathrm{b}}$ & Std. Deviation & .0000000 \\
& Absolute & .119 \\
& Positive & .097 \\
Most Extreme Differences & Negative & -.119 \\
& & .801 \\
Kolmogorov-Smirnov Z & & .543 \\
Asymp. Sig. (2-tailed) & & \\
\hline
\end{tabular}

a. Test distribution is Normal.

b. Calculated from data.

Based on the table in the table above the Kolmogorov-Smirnov $\mathrm{Z}$ value is 0.801 and a probability value of 0.543 shows that the probability

value is greater than the significant value of 0.05 , so it can be concluded that the data are normally distributed.

\section{Zmijewski Model Normality Test Results}

Table 8. Zmijewski Model Normality Test Results One-Sample Kolmogorov-Smirnov Test

\begin{tabular}{|ll|c|}
\hline & & $\begin{array}{c}\text { Unstandardized } \\
\text { Residual }\end{array}$ \\
\hline $\mathrm{N}$ & Mean & 45 \\
Normal Parameters ${ }^{\mathrm{a}, \mathrm{b}}$ & Std. Deviation & .0000000 \\
& Absolute & .0000000 \\
& Positive & .103 \\
Most Extreme Differences & Negative & -.079 \\
& & .690 \\
Kolmogorov-Smirnov Z & & .729 \\
Asymp. Sig. (2-tailed) & & \\
\hline
\end{tabular}


a. Test distribution is Normal.

b. Calculated from data.

Based on the table in the table above the Kolmogorov-Smirnov $\mathrm{Z}$ value is 0.690 and the probability value is 0.729 , this shows that the probability value is greater than the significant value of 0.05 , so it can be concluded that the data are normally distributed.

\section{Ohlson Model Normality Test Results}

Table. 9 Ohlson Model Normality Test Results

One-Sample Kolmogorov-Smirnov Test

\begin{tabular}{|ll|c|}
\hline & & $\begin{array}{c}\text { Unstandardized } \\
\text { Residual }\end{array}$ \\
\hline $\mathrm{N}$ & Mean & 45 \\
Normal Parametersa,b & Std. Deviation & .47397076 \\
& Absolute & .120 \\
Most Extreme Differences & Positive & .098 \\
& Negative & -.120 \\
Kolmogorov-Smirnov Z & & .806 \\
Asymp. Sig. (2-tailed) & & .535 \\
\hline
\end{tabular}

a. Test distribution is Normal.

b. Calculated from data.

Based on the table in the table above the Kolmogorov-Smirnov $\mathrm{Z}$ value is 0.806 and the probability value of 0.535 shows that the probability value is greater than the significant value of 0.05 , so it can be concluded that the data are normally distributed.

\section{Research Hypothesis Test Results Paired Sample t-test}

Table 10. Paired Sample t-test

Paired Samples Test

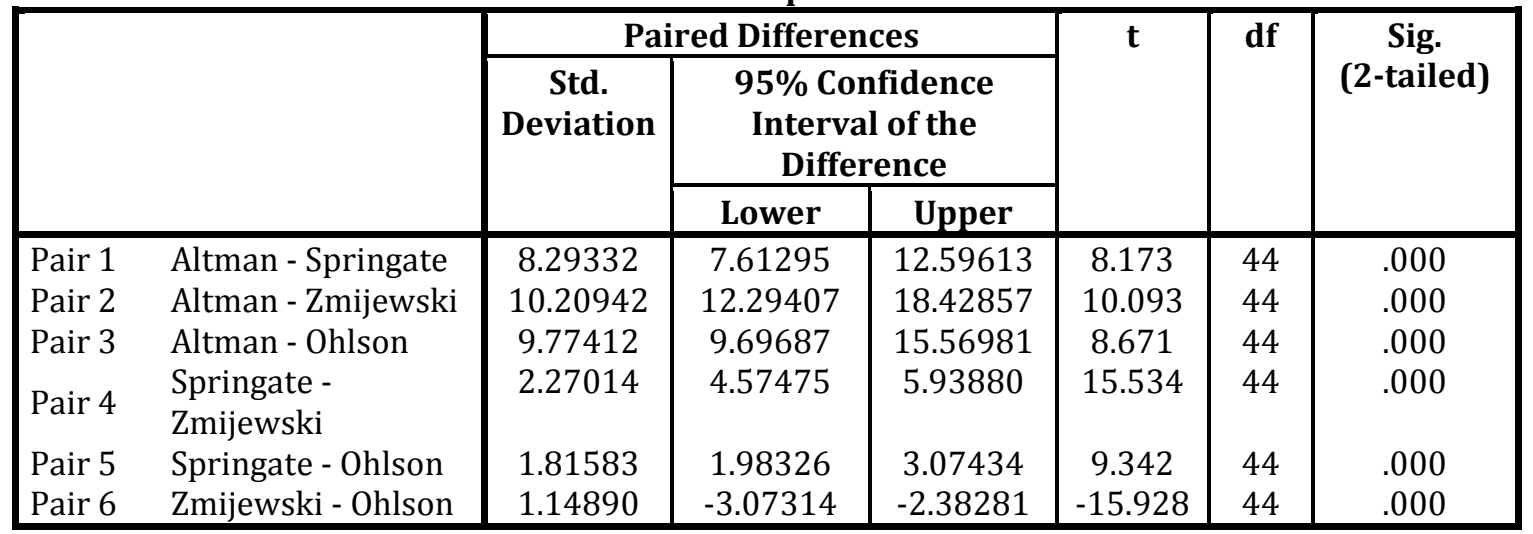

Based on the results of the output in table 4 there is a Sig. (2-tailed) of 0,000 in pair 1 between the Altman and Springate model scores, pair 2 between the Altman and Zmijewski models, pair 3 between the Atman and Ohlson models, pair 4 between the Springate and Zmijewski models, pair 5 between Springate and Ohlson and pair 6 between Zmijewski and Ohlson. These results indicate a probability $<0.05$, which means that there are significant differences between the two sample groups.

\section{Discussion of Research Results}

H1 : There is a difference in the results of the analysis of financial distress potential between the Altman Z-Score and Springate models

Based on the paired sample t-test results in table 10 shows the results of the significance of $0.00<0.05$ so it can be concluded that $\mathrm{H} 1$ is accepted; namely, there are differences in the results of the analysis of financial distress potential between the Altman Z-Score model with Springate with a 95\% 
confidence level. These results are in line with previous research by Dimas (2017), which states that there are differences between the Altman Z-Score and Springate models. The results of this study are also in line with Fitriani (2016), which says that there are differences between the Altman Z-Score and Springate models.

$\mathrm{H} 2$ : There are differences in the results of the analysis of potential financial distress between the Altman Z-Score model and Zmijewski

Based on the paired sample t-test results in table 10 shows the results of the significance of $0.00<0.05$ so it can be concluded that $\mathrm{H} 2$ is accepted; namely there are differences in the results of the analysis of financial distress potential between the Altman Z-Score model with Zmijewski with a 95\% confidence level. These results are in line with previous research by Dimas (2017), which states that there are differences between the Altman Z-Score and Zmijewski models. The results of this study are also in line with Wulandari (2014), which says that there are differences between the Altman Z-Score and Zmijewski models.

H3 : There are differences in the results of the analysis of financial distress potential between the Altman Z-Score model and Ohlson

Based on the paired sample t-test results in table 10 shows the results of the significance of $0.00<0.05$ so it can be concluded that $\mathrm{H} 3$ is accepted; namely there are differences in the results of the analysis of financial distress potential between the Altman Z-Score model with Ohlson with a 95\% confidence level. The results of this study are in line with Wulandari (2014), which states that there are differences between the Altman Z-Score and Ohlson models. While the results of Fairuz's (2016) research concluded that there was no difference between the Altman Z-Score and Ohlson models.

H4 : There are differences in the results of the analysis of financial distress potential between the Springate model and Zmijewski

Based on the paired sample t-test results in table 10 shows the results of the significance of $0.00<0.05$ so it can be concluded that $\mathrm{H} 4$ is accepted; namely, there are differences in the results of the analysis of financial distress potential between the Springate and Zmijewski models with a $95 \%$ confidence level. The results of this study are in line with Gustina (2015), which states that there are differences between the Springate and Zmijewski models. The results of this study are also in line with Randy (2017) which says that there are differences between the Springate and Zmijewski models

H5 : There is a difference in the results of the analysis of the potential for financial distress between the Springate and Ohlson models

Based on the paired sample t-test results in table 10 shows the results of the significance of $0.00<0.05$ so it can be concluded that H5 is accepted; namely there are differences in the results of the analysis of financial distress potential between the Springate and Ohlson models with a 95\% confidence level. The results of this study are in line with Gustina (2015), which states that there are differences between the Springate and Ohlson models.

H6: There are differences in the results of the analysis of the potential for financial distress between the Zmijewski and Ohlson models

Based on the paired sample t-test results in table 10 shows the results of the significance of $0.00<0.05$ so it can be concluded that H6 is accepted; namely there are differences in the results of the analysis of financial distress potential between Zmijewski and Ohlson models with a $95 \%$ confidence level. The results of this study are in line with Wulandari (2014), which states that there are differences between the Springate and Ohlson models.

\section{CONCLUSION}

1. There are significant differences between the Altman, Springate, Zmijewski, and Ohlson models. In the Altman Z-Score model, there are no samples that are predicted to experience financial distress, but 8 samples are predicted to be prone to financial distress. In contrast, in the Springate model, 7 samples are experiencing financial distress, and 2 samples are prone to financial distress. In the Zmijewski model, there are no samples that are predicted to experience financial distress or are likely to financial distress. In the Ohlson model, 10 samples are predicted to experience financial distress.

2. The Altman Z-Score model is the most accurate in predicting financial distress conditions in pharmaceutical sector companies listed on the Stock Exchange in $2013-2017$ 


\section{REFERENCES}

1. Alostaz, A.O. (2015). Predicting Corporate Failure Using Cash Flow Statement Based Measures -An Empirical Study on the Listed Companies in the Palestine Exchangell Islamic University of Gaza

2. Altman, Edward L. 1968. Financial Ratios, Discriminant Analysis and the Prediction of Corporate Bankruptcy. Journal of Finance.pp 589-609.

3. Andrianti. 2016. Analisis Ketepatan Model Altman, Springate, Zmijewski, Ohlson dan Grover sebagai Detektor Kebangkrutan (Studi Kasus pada Perusahaan Delisting di Bursa Efek Indonesia (BEI) pada tahun 2010-2014. Jurnal Universitas Islam Negeri Maulana Malik Ibrahim Malang

4. Brigham, E.F. \& Houston, J.F. 2014. Dasar-Dasar Manajemen Keuangan. Edisi Kesepuluh. Jakarta: Salemba Empat

5. Drescher, F. 2014. Insolvency Timming and Managerial Decision-Making. Springer, Munchen.

6. Edi dan May Tania. 2017. Ketepatan Model Altman, Springate, Zmijewski, Dan Grover Dalam Memprediksi Financial Distress. Jurnal Reviu Akuntansi dan Keuangan Vol 8, No.1

7. Fahmi, Irham. 2014. Analisis Kinerja Keuangan: Panduan Bagi Akademisi, Manajer, dan Investor Untuk Menilai dan Menganalisis Bisnis dari Aspek Keuangan. Bandung: Alfabeta

8. Fairuz Zabady Zainal Abidin Putera dkk. 2016. Perbandingan Prediksi Financial Distress Dengan Menggunakan Model Altman, Springate Dan Ohlson. Jurnal Universitas Lambung Mangkurat, Vol. 4 No. 3

9. Fawzi, Noor Salfizan .,Kamaludin, Amrizah, Sanusi Mohd, Zuraidah, 2015, Monitoring Distressed Companies through Cash Flow Analysis, 7th international conference on financial criminology, $2015 \quad 13-14$ April 2015, Wadham College, Oxford, United Kingdom

10. Fitriani Rahayu dkk. 2016. Analisis Financial Distress Dengan Menggunakan Altman Z-Score, Springate, Dan Zmijewski Pada Perusahaan Telekomunikasi. E-Journal Universitas Pendidikan Ganesha

11. Gandhy, F. (2019). Analysis of Financial Ratio to Predict Financial Distress Conditions (Empirical Study on Manufacturing Companies listed on the Indonesia Stock Exchange for 2014-2017). IJBMI PP 27-34.

12. Gunawan, Barbara. 2017. Perbandingan Prediksi Financial Distress dengan Model Altman, Grover dan Zmijewski. Jurnal Akuntansi dan Investasi, Vol. 18 No. 1

13. Hidayat, Gustina. 2015. Analisis Dalam Memprediksi Kebangkrutan Dengan Menggunakan Multiple Discriminant Analysis Dan Logit Pada Industri Farmasi Yang Terdaftar Di Bursa Efek Indonesia Periode 2009-2014. Jurnal Telkom University
14. Hidayat, K. N., Glasbergen, P., \& Offermans, A. (2015). Sustainability certification and palm oil smallholders' livelihood: a comparison between scheme smallholders and independent smallholders in Indonesia. International Food and Agribusiness Management Review, 18(1030-2016-83041), 25-48.

15. Husein, P, M., \& T.G. Pambekti. (2014). Precision of the models of Altman, Springate, Zmijewski, and Grover for predicting the financial distress. Journal of Economics, Business, and Accountancy Ventura, 17(3): 405-416 22.

16. Iskandar, Diah, et.al (2019). Analysis of Financial Performance in Predicting Financial Distress in Mining Companies., Saudi Journal Economic and Finance. Dec 2019; 3(12): 601-609

17. Jones, S., \& Hensher, D. A. (2004). Predicting firm financial distress: A mixed logit model, The Accounting Review, 79(4): 1011-1038.

18. Khoiriyah, Safinatun. 2019. Analisis Financial Distress, Perbandingan dan Tingkat Akurasi Menggunakan Model Altman Z-Score, Grover, Springate dan Zmijewski untuk Memprediksi Kebangkrutan pada Perusahaan. Jurnal Institut Agama Islam Negeri Surakarta

19. Musthafa. 2017. Manajemen Keuangan. Yogyakarta: Andi Offset

20. Ohlson, James A. 1980. Financial Ratios and Probabilistic Prediction of Bankruptcy. Journal of Accounting Research.

21. Permana, R. K., Ahmar, N., \& Djadang, S. (2017). Prediksi Financial Distress pada Perusahaan Manufaktur di Bursa Efek Indonesia. Esensi: Jurnal Bisnis dan Manajemen, 7(2), 149-166. 23. Jones, S. (2016). A cash flow based model of corporate bankruptcy in Australia. Journal of Applied Management Accounting Research, 14(1), 23.

22. Priambodo, Dimas. 2017. Analisis Perbandingan Model Altman, Springate, Grover, Dan Zmijewski Dalam Memprediksi Financial Distress (Studi Empiris Pada Perusahaan Sektor Pertambangan Yang Terdaftar Di Bursa Efek Indonesia Periode 2012-2015). Skripsi Universitas Negeri Yogyakarta

23. Putri, Andi Eka Pratiwi. 2018. Analisis Perbandingan Kondisi Financial Distress Menggunakan Model Altman, Springate, Dan Zmijewski Pada Perusahaan Manufaktur

Yang Terdaftar Di Bursa Efek Indonesia. Jurnal Universitas Makassar

24. Randy Kurnia Permana dkk. 2017. Prediksi Financial Distress pada Perusahaan Manufaktur di Bursa Efek Indonesia. E-Journal Universitas Islam Negeri Syarif Hidayatullah Jakarta

25. Rodoni, Ahmad \& Herni Ali. 2014. Manajemen Keuangan Modern. Jakarta. Mitra Wacana Media

26. Scholars Middle East Publishers, Dubai, United Arab Emirates. , Dec 2019; 3(12): 601-609 
27. Sjahrial, Dermawan. 2014. Manajemen Keuangan Lanjutan Edisi Revisi. Jakarta: Mitra Wacana Media

28. Springate, Gordon L.V. 1978. Predicting the Possibility of Failure in a Canadian Firm. M.B.AResearch Project,Simon Fraser University.January

29. Sugiyono. 2014. Metode Penelitian Kuantitatif, Kualitatif, dan R\&D. Bandung: Alfabeta

30. Sugiyono. 2016. Metode Penelitian Kuantitatif, Kualitatif, dan R\&D. Bandung: Alfabeta

31. Sugiyono. 2017. Metode Penelitian Kuantitatif Kualitatif, dan R\&D. Bandung: Alfabeta

32. Supriyono, R.A. $2018 . \quad$ Akuntansi Biaya.Yogyakarta. BPFE

33. Tanjung, Putri Renalita Sutra \& Dewi Anggraini. (2020). Saudi Journal Economic and Finance. Published by Scholars Middle East Publishers, Dubai, United Arab Emirates Jan 2020; 4(1): 1-11

34. Veronita, Wulandari, , Emrinaldi, Nur DP dan Julita. 2014. Analisis Perbandingan Model Altman, Springate, Ohlson, Fulmer, CA-Score dan Zmijewski Dalam Memprediksi Financial Distress (studi empiris pada Perusahaan Food and Beverages yang Terdaftar di Bursa Efek Indonesia Periode 2010-2012). Jurnal Fakultas Ekonomi Universitas Riau.

35. Wati, Lela Nurlela. 2018. Metodologi Penelitian Terapan Aplikasi SPSS, EVIEWS, Smart PLS dan AMOS. Edisi Kedua. Jakarta: Pustaka Amri

36. Zmijewski, Mark. 1983. Predicting Corporate Bankruptcy: An Empirical Comparison of the Extant Financial Distress Models. Working paper. SUNY at Buffalo 